\title{
PENGEMBANGAN BUDAYA SUKU TALANG MAMAK SEBAGAI NILAI-NILAI KEARIFAN LOKAL DALAM BAGIAN CIVIC CULTURE (Studi Etnografi pada masyarakat suku Talang Mamak di Kecamatan Rakit Kulim, Kabupaten Indragiri Hulu, Propinsi Riau)
}

\author{
Islamuddin, Prodi Pendidikan Kewarganegaraan, SPs, Universitas Pendidikan Indonesia, \\ email: Islamuddin.Saini88@gmail.com
}

\begin{abstract}
ABSTRAK
Penelitian ini dilatarbelakangi oleh terjadinya sebuah degradasi kebudayaan dan kearifan lokal yang menyebabkan menculnya gejala krisis jati diri dan krakter bangsa, rendahnya pengetahuan mengenai kebudayaan, dan Rendahnya plestarian kebudayaan yang terjadi dalam masyarakat bangsa Indonesia. Dalam penelitian ini ini mendiskripsikan budaya suku Talang Mamak dalam bagian civic culture, mendiskripsikan kearifan lokal dalam bagian civic culture, Pelestarian kebudayaan dan kearifan lokal suku Talang Mamak dan Kendala dan Upaya dalam pelestarian kebudayaan dan kearifan lokal masyarakat suku Talang Mamak. Pendekatan penelitian menggunakan pendekatan kualitatif dengan metode etnografi. Pengumpulan data menggunakan observasi, wawancara, dokumentasi, dan triangulasi. Tehnik analisis data dengan menggunakan reduksi data, display data dan Verifikasi data. Kesimpulan bahwa budaya masyarakat suku Talang Mamak merupakan bagian dari civic culture dibuktikan dengan adanya nilai-nilai civic culture, kearifan lokal masyarakat suku Talang Mamak bagian dari civic culture dengan adanya nilai-nilai civic culture, pelestarian dilakukan dengan cara memberikan pengetahuan mengenai kebudayaan Talang Mamak, mengikuti lomba antar kebudayaan, dan festival kebudayaan. Kendala dalam pelestarian meliputi: faktor ekonomi, faktor pendidikan yang rendah, dan faktor transporatasi.
\end{abstract}

\section{PENDAHULUAN}

Daerah lokasi penelitian ini dilaksanakan di kecamatan Rakit Kulim meliputi desa Talang Gedabu, Desa Talang Parit, Desa Talang Sungai Limau, Desa Talang Durian Cacar, Desa Talang Tujuh Tangga, dan Desa Talang Selantai. Daerah ini di kenal dengan tujuh talang merupakan daerah yang paling domain di tempati oleh masyarakat suku Talang Mamak. Daerah ini juga merupakan daerah awal perkembangan kebudayaan suku Talang Mamak di Kecamatan Rakit Kulim.

Menurut Taylor dalam Horton \& Chester, 1996:58; Harsojo, 1988:92; Soekanto; 2003:172; Sutarno. 2008:5: Sulaeman, 2012:35 dan Kusumohamidjojo, 2010:38 menyebut bahwa kebudayaan adalah kompleks keseluruhan dari pengetahuan, keyakinan, kesenian, moral, hukum, adat istiadat dan semua kemampuan dan kebiasaan yang lain yang diperoleh oleh seseorang sebagai anggota masyarakat.
Kebudayaan suku Talang Mamak memiliki pengetahuan, kepercayaan, seni, moral, hukum, adat-istiadat, serta kemampuan-kemampuan dan kebiasaan lainnya yang diperoleh manusia sebagai anggota masyarakat. Menurut Ruben (2009) Kebudayaan masyarakat suku Talang Mamak meliputi, Menambak/naik tanah, Cuci lantai, Gawai, Mendanau, Berjudi, MenyaMbung ayam, Meratap, Merota, dan Hari Menuju. Selanjutnya Elfidayati, (2013) mengatakan kebudayaan suku Talang Mamak yaitu:

Suku Talang Mamak berisikan upacara-upacara adat seperti gawai yaitu pesta pernikahan, kemantan yaitu pengobatan penyakit, tambat kubur yaitu acara seratus hari kematian dan memperbaiki kuburan untuk peningkatan status sosial, khitanan, upacara melahirkan dibantu oleh dukun, upacara timbang bayi, upacara beranggul yaitu upacara yang tujuannya untuk 
menghibur orang yang sedang mengalami kemalangan.

Selain itu, masyarakat Talang Mamak juga memiliki sebuah bahasa dibuktikan dengan adanya bahasa Talang Mamak, sistem pengetahuan dibuktikan dengan pemanfaatan tumbuhan sebagai obat, organisasi sosial dibuktikan dengan adanya kempemimpian suku Talang Mamak yang di pimpin oleh Patih, sistem peralatan hidup dan teknologi dibuktikan dengan adanya cangkul, beliung, parang dan pisau, sistem mata pencaharian hidup dibuktikan dengan adanya ladang, sistem relegi dibuktikan dengan adanya animisme, islam, dan kristen dan kesenian dibuktikan dengan adanya tarian rentak bulian.

Dari penjabaran diatas masyarakat suku Talang Mamak sudah memiliki kebudayaan yang meliputi wujud kebudayaan berupa ide, gagasan, nilai dan norma yang berlaku dalam kehidupannya. Serta memiliki sebuah unsur kebudayaan dalam melaksanakan kehidupan adatnya. Oleh sebab itu, masyarakat Talang Mamak harus memajukan, menghormati, dan memlihara kebudayaan yang ada dalam kehidupan suku Talang Mamak.

Dalam upaya memajukan, menghormati dan memelihara kebudayaan suku Talang Mamak diatas telah diatur oleh konstitusi Undang-Undang Dasar Negara Republik Indonesia Tahun 1945 pada pasal 32 ayat 1 dan 2 sebagai berikut: 1) Negara memajukan kebudayaan nasional Indonesia di tengah peradaban dunia dengan menjamin kebebasan masyarakat dalam memilihara dan mengembangkan budayanya; 2) Negara menghormati dan memelihara bahasa daerah sebagai kekayaan budaya nasional.

Undang-Undang Dasar 1945 pasal 32 mengamanatkan bahwa negara memajukan kebudayaan nasional Indonesia di tengah peradaban dunia dengan menjamin kebebasan masyarakat dalam memelihara dan mengembangkan nilai-nilai budayanya. Dalam konteks ini, pemerintah menjamin kebebasan masyarakat dalam memelihara dan mengembangkan nilai-nilai budaya yang tumbuh dan berkembang di masyarakat Indonesia. Pada era globalisasi, pemerintah berkewajiban melindungi dan melayani masyarakat dalam memelihara dan mengembangkan nilai-nilai budaya lokal agar tidak tergerus oleh dampak negatif budaya global.

Maka dari pada itu, sebuah Negara harus mempertahankan budaya warga negaranya. Hal tersebut dilakukan agar bangsa Indonesia tidak kehilangan jati diri dan identitas bangsanya yang disebabkan oleh masuknya dampak negatif kebudayaan asing yang mempengaruhi pola kehidupan bangsa Indonesia. Sesuai dengan pendapat Rosidi, (2011:32) bahwa "arah yang mereka tujukan adalah masa depan bangsa kita sekarang yang juga sedang menghadapi pengaruh atau lebih tepat terjangan kebudayaan Barat dalam hampir seluruh bidang kehidupan kita sebagai bangsa Indonesia". Degradasi kebudayaan yang terjadi di Indonesia sedikit kecil berpengaruh terhadap kebudayaan mayarakat suku Talang Mamak yang sudah mulai terkikis, sehingga perlu kembali menanamkan nilai-nilai kearifan lokal yang terkandung di dalam kebudayaan suku Talang Mamak. Kearifan lokal dalam menghadapi pengaruh yang datang dari luar yang dianggap sebagai tantangan. Sebagai bangsa, sudah membuktikan bahwa menghadapi semua terjangan pengaruh dari berbagai kebudayaan yang datang dari luar telah menghasilkan akulturasi sewaktu-waktu bisa menenggelamkan nilai-nilai kearifan lokal yang terkandung di dalam masyarakat suku Talang Mamak. Maka dari pada itu, melalui nilai kearifan lokal merupakan upaya untuk mempertahakan sebuah budaya dalam suatu bangsa, termasuk suku Talang Mamak. Haryati Soebadio dalam Ayatrohaedi, (1986:18-19) mengatakan lokal genius adalah cultural identity, identitas budaya bangsa yang menyebabkan bangsa tersebut mampu menyerap dan mengolah kebudayaan asing sesuai watak dan kemampuan sendiri. Oleh sebab itu, perlunya sebuah kemampuan dalam masyarakat suku Talang Mamak untuk melestarikan budaya dan kearifan lokal dalam masyarakat suku Talang Mamak. Menurut Anggoro, (2010) terdapat pepatah yang mengatakan "Lebih baik saya ditembak dari pada kehilangan hutan adat" 
atau sebuah pepatah kuno oleh orang suku Talang Mamak yang menyatakan "lebih baik mati anak, daripada mati adat".

Masyarakat suku Talang Mamak mengalami degradasi fungsi kearifan lokal salah satunya mengenai hutan adat disebabkan hutan adat banyak digarap perusahaan menjadi sebuah industri, membuat sejumlah tokoh masyarakat suku Talang Mamak mulai berfikir kembali untuk mempertahankan hutan adat, kebudayaan dan nilai kearifan lokal. Padahal nilai yang terdapat sangat luhur sekali dan patut menjadi kebangaan nasional dan dengan demikian menjadi modal untuk mengreasikan kearifan lokal. Untuk mengembangkan kembali nilai kearifan lokal salah satu bidang ilmu yang mengkaji tentang budaya daerah atau nilai kearifan lokal yang terdapat di dalam warga negara adalah civic culture.

Menurut Winataputra (2012:57) Spesifik civic culture merupakan "budaya yang menopang kewarganegaraan yang berisikan separangkat ide-ide yang dapat diwujudkan secara efektif dalam representasi kebudayaan untuk tujuan pembentukan identitas warganegara". Masyarakat suku Talang Mamak dari konsep budaya warganegara (civic culture) merupakan bagian dari jati diri bangsa, karakter bangsa, suku bangsa, dan nilai-nilai kearifan lokal. Maka dari itu, pendidikan kewarganegaraan mempunyai peranan penting untuk mempertahankan identitas bangsanya melalui budaya yang terdapat di dalam warganegara Indonesia termasuk masyarakat suku Talang Mamak.

Pada dasarnya, setiap warganegara yang ada di dalam sebuah negara mempunyai sebuah budaya yang berbeda-beda, sehingga diperlukannya sebuah pengetahuan mempersatukan perbedaan-perbedaan budaya dengan cara memberikan pengetahuan mengenai budaya-budaya lokal yang terdapat dalam negara Indonesia. Pendidikan Kewarganegaraan yang mengkaji tentang budaya yaitu civic culture. Winataputra (2006:58) menyatakan "bahwa identitas warga negara yang bersumber dari civic culture perlu dikembangkan melalui pendidikan kewarga- negaraan dalam berbagai bentuk dan latar belakang".

Maka daripada pengembangan sebuah budaya juga harus dilandaskan kepada pengetahuan warganegara mengenai etnis yang terdapat disekitarnya dan dapat mempertahankan sebuah kebudayaan dan kearifan lokal dengan membentuk sebuah jati diri dan karakter bangsa dengan mengedepankan pembentukan identitas bangsa.

Permasalahan yang dihadapi dalam kebudayaan masyarakat suku Talang Mamak di daerah Rakit Kulim antara lain munculnya gejala krisis jati diri dan karakter bangsa yang disebabkan oleh dampak negatif globalisasi dan kemajuan teknologi komunikasi dan informasi yang membuka peluang terjadinya interaksi budaya antar bangsa, masih rendahnya kesadaran masyarakat terhadap upaya pelestarian nilai budaya dan kearifan lokal yang disebabkan semakin terbatasnya ruang atau tempat penyaluran aspirasi kreativitas seni budaya masyarakat; dan kurangnya apresiasi dan rasa cinta terhadap budaya dan produk dalam negeri, masih rendahnya apresiasi, pemahaman, komitmen, dan kesadaran tentang kekayaan budaya dengan berbagai kandungan nilainilai luhurnya yang mengakibatkan terbatasnya pengelolaan kekayaan budaya oleh pemerintah daerah, karena terbatasnya kemampuan keuangan maupun kemampuan manajerial dan belum optimalnya sumber daya di bidang kebudayaan, baik dari sisi kualitas maupun kuantitas. Serta rendahnya sumber daya manusa yang ada dalam masyarakat suku Talang Mamak sehingga bisa menyebabkan mudahnya pengaruhpengaruh dari luar sehingga memudarnya kebudayaan dan kearifan lokal yang terdapat dalam masyarakat suku Talang Mamak. Oleh sebab itu, maka perlunya untuk meneliti mengenai kebudayaan dan kearifan lokal yangn terdapat dalam masyarakat suku Talang Mamak agar tidak hilang maka dari itu, untuk mempermudah penelitian ini, maka sub rumusan masalah yang terdapat dalam penelitian ini sebagai berikut: (1) Bagaimana diskripsi budaya suku Talang Mamak dalam bagian civic culture?, (2) Bagaimana nilai- 
nilai kearifan lokal yang terkandung dalam budaya masyarakat suku Talang Mamak dalam bagian civic culture?, (3) Bagaimana pelestarian kebudayaan dan nilai-nilai kearifan lokal yang terkandung dalam budaya masyarakat suku Talang Mamak, dan (4) Bagaimana kendala dan upaya dalam pelestarian kebudayaan dan nilai-nilai kearifan lokal yang terkandung dalam budaya masyarakat suku Talang Mamak?.

Adapun yang menjadi tujuan penelitian ini sebagai berikut: (1) Mendeskripsikan budaya masyarakat suku Talang Mamak dalam bagian civic culture. (2) Mengidentifikasikan nilai-nilai kearifan lokal yang terkandung dalam budaya masyarakat suku Talang Mamak dalam bagian civic culture. (3) Mendiskripsikan pelestarian nilai-nilai kearifan lokal yang terkandung dalam budaya masyarakat suku Talang Mamak dalam bagian civic culture. (4) Mendiskripsikan kendala dan upaya dalam pelestarian nilainilai kearifan lokal yang terkandung dalam budaya masyarakat suku Talang Mamak dalam bagian civic culture.

\section{KEBUDAYAAN SUKU TALANG MAMAK}

Sir Edward Burnett Taylor dalam Horton \& Chester, 1996:58; Harsojo, 1988:92; Soekanto; 2003:172; Sutarno. 2008:5: Sulaeman, 2012:35 dan Kusumohamidjojo, 2010:38 menyebut bahwa kebudayaan adalah kompleks keseluruhan dari pengetahuan, keyakinan, kesenian, moral, hukum, adat istiadat dan semua kemampuan dan kebiasaan yang lain yang diperoleh oleh seseorang sebagai anggota masyarakat. Sedangkan Menurut Geertz (1973:89): Kebudayaan adalah "pola dari pengertianpengertian atau makna yang terjalin secara menyeluruh dalam simbol-simbol yang ditransmisikan secara historis, suatu sistem mengenai konsepsi-konsepsi yang diwariskan dalam bentuk-bentuk simbolik yang dengan cara tersebut manusia berkomunikasi, melestarikan, dan mengembangkan pengetahuan dan sikap mereka terhadap kehidupan." Selanjutnya Menurut Wiranata, 2011:96-97 dari sekian banyak pemikiran para ahli tentang apakah sesungguhnya kebudayaan itu, secara umum inti pengerti kebudayaan :

1) Bahwa kebudayaan yang terdapat antara umat manusia itu sangat beraneka ragam,

2) Bahwa kebudayaan itu didapat dan diteruskan secara sosial melalui proses pembelajaran,

3) Bahwa kebudayaan itu terjabarkan dari komponen biologis, sosiologis, dan psikologis dari eksistensi manusia,

4) Bahwa kebudayaan itu berstruktur,

5) Bahwa kebudayaan itu memuat beberapa aspek,

6) Bahwa kebudayaan itu bersifat dinamis, dan

7) Bahwa nilai dalam kebudayaan itu bersifat relatif

Menurut Elfidayati, (2013) mengatakan tentang kebudayaan suku talang mamak yaitu:

"suku talang mamak berisikan upacaraupacara adat seperti gawai yaitu pesta pernikahan, kemantan yaitu pengobatan penyakit, tambat kubur yaitu acara seratus hari kematian dan memperbaiki kuburan untuk peningkatan status sosial, khitanan, upacara melahirkan dibantu oleh dukun, upacara timbang bayi, upacara beranggul yaitu upacara yang tujuannya untuk menghibur orang yang sedang mengalami kemalangan".

Sejalan dengan pendapat diatas menurut Ruben, (2009) tradisi-tradisi Suku Talang Mamak adalah sebagai berikut:

1. Kumantan: suatu acara berdukun untuk mengobati penyakit dan memberi makan pelindung kampung. Pada acara ini orang-orang yang akan diobati duduk di dekat dukun. Dukun menari-nari diikuti iringan musik dari alat musik tawak-tawak dan katubung. Sambil menari-nari dukun siap sedia untuk dimasuki roh leluhur. Acara berdukun dilakukan pada larut malam, biasanya sekitar jam 22.00.

2. Menambak/naik tanah: yakni suatu acara menimbun kuburan. Orang Talang Mamak bila meninggal akan dikuburkan, tetapi kuburan tidak 
langsung ditimbun penuh dengan tanah, melainkan hanya sedikit saja di bagian permukaan. Tanah itu ditahan dengan papan. Setelah 100 hari bila keluarga sepakat maka kuburan itu ditimbun dengan tanah dan diberi tanda. Itulah acara menambak.

3. Cuci lantai: yakni suatu acara adat yang berlaku untuk anak-anak yang baru lahir. Dalam acara ini si anak diberi nama dan akan mendapatkan orang tua asuh. Si anak juga akan dibawa ke sungai dan dimandikan di sana.

4. Gawai: yakni acara pernikahan. Pernikahan bisa terjadi bila pemuda dan pemudi sudah saling mencintai dan sepakat untuk berkeluarga. $\mathrm{Si}$ wanita akan mengikut ke rumah silakilaki dengan membawa pertanda dari laki-laki itu. Kemudian mereka akan naik ke rumah mangku, selanjutnya ke rumah batin. Akan tetapi perkawinan juga bisa terjadi bila pemuda dan pemudi kedapatan sedang berduaan pada malam hari. Yang seperti ini disebut dengan tergawal. Mereka akan langsung dinikahkan.

5. Mendanau: yakni suatu acara mencari ikan secara bersama ke suatu kolam.

6. Berjudi: berjudi juga merupakan acara adat dan dilaksanakan pada saat adanya pesta-pesta.

7. Menyabung ayam: menyabung ayam juga acara adat dan dilaksanakan pada pesta. Pada saat itu orang-orang akan saling bertaruh dengan uang.

8. Meratap: yakni suatu acara menangisi orang yang meninggal.

9. Merota: yakni acara masuk ke liang kubur oleh keluarga yang meninggal sebagai tanda bahwa dia tidak rela keluarganya meninggal, lebih baik dirinya yang meninggal. Ini tanda cinta kepada yang meninggal itu.

10. Hari Menuju: yakni acara bagi yang sudah meninggal 7 hari. Pada acara ini roh yang meninggal diantar ke tempatnya dengan tanda menebarkan daun-daun pisang di jalan sebagai jalan arwah yang meninggal.

\section{KEARIFAN LOKAL}

Menurut Sartini, (2004:111 lokal wisdom (kearifan setempat) dapat dipahami sebagai gagasan-gagasan setempat (lokal) yang bersifat bijaksana, penuh kearifan, bernilai baik, yang tertanam dan diikuti oleh anggota masyarakatnya.

Menurut Moendardjito dalam Ayat Rohaedi, (1986:40-41) mengatakan bahwa unsur budaya daerah potensial sebagai lokal genius karena telah teruji kemampuannya untuk bertahan sampai sekarang. Ciricirinya adalah :

a. Mampu bertahan terhadap budaya luar.

b. Memiliki kemampuan mengakomodasi unsur-unsur budaya luar.

c. Mempunyai kemampuan mengintegrasikan unsur budaya luar ke dalam budaya asli.

d. Mempunyai kemampuan mengendalikan.

e. Mampu memberi arah pada perkembangan budaya.

Menurut Alwasih, et al (2009:51) menyebut ciri-ciri kearifan lokal sebagai berikut:(1) berdasarkan pengalaman, (2)Teruji setelah digunakan berabad-abad, (3) dapat diadaptasi dengan kultur kini, (4) padu dalam praktek keseharian masyarakat dan lembaga, (5) lazim dilakukan oleh individu atau masyarakat secara keseluruhan, (6) bersifat dinamis dan terus berubah, dan (7) terkait dengan sistem kepercayaan.

Sejalan dengan pandangan tersebut, Wagiran (2012:330) merumuskan sebagai berikut :

Lokal wisdom is the knowledge that discovered or acquired by lokal people thourgh the accumulation of experiences in trials and integrated with the understanding of surrounding nature and culture. Lokal wisdom is dynamic by funcation of created lokal wisdom and connected to the global situation.

Secara umum karakteristik lokal memberikan pandangan tentang kearifan lokal telah digunakan secara turun menurun 
oleh para pelaku budayanya, kearifan lokal tidak akan pernah lepas dari ruang lingkup kebudayaanya, kepercayaan dan keterkaitan antara lingkungan alam dan sosial yang ada disekitarnya.

Ungkapan itu menurut Isjoni, (2005:7071) yaitu : "Utang laki-laki kepada bini, dicarikan lauk, dicarikan asam garam, dibuatkan buma, utang bini kepada laki digulaikan ikan, disendokan dan disajikan makanan, tikar dibentangkan, kelambu digayutkan".

\section{BUDAYA KEWARGANEGARAAN (CIVIC CULTURE)}

Menurut Winataputra (2012:57) Spesifik civic culture merupakan budaya yang menopang kewarganegaraan yang berisikan separangkat ide-ide yang dapat diwujudkan secara efektif dalam representasi kebudayaan untuk tujuan pembentukan identitas warganegara. Senada dengan pendapat diatas menurut Winataputra \& Budimansyah. (2012:233) Civic culture merupakan budaya yang menopang kewarganegaraan yang berisikan ....a set of ideas that can be embodied effectively in cultural representtations for the purpose of shaping civic identities atau seperangkat ide-ide yang dapat diwujudkan secara efektif dalam representasi kebudayaan untuk tujuan pembentukan identitas warga negara.

Menurut Winataputra, (2006:62) unsur dari budaya kewarganegaran (civic culture) adalah civic virtue atau kebajikan atau ahlak kewarganegaraan yang mencakup keterlibatan aktif warganegara, hubungan kesejajaran/egaliter, saling percaya dan toleran, kehidupan yang kooperatif, solidaritas, dan semangat kemasyarakatan.

Putnam, (1994) dalam Budimansyah \& Suryadi. (2008:186-187) Partisipasi ini dibangun atas hal-hal yang mendasar, yaitu

a) Egalitarianism atau hubungan timbal balik secara horizontal sesama warga.

b) Pluralisme, dimana perbedaan paham, kepercayaan, dan kepentingan sesame warga diterima sebagai kenyataan hidup yang harus dihargai, karena itu toleransi sosial politik memberi ciri krusial terhadap civic community.

c) Rasa saling percaya (trust) dan solideritas sesama warga.

Menurut Denny.J.A. (2006:52) Kini term civic culture ini digunakan sebagai label untuk merangkum berbagai nilai dan prilaku yang memperkukuh institus demokrasi. Elemen civic culture itu antara lain: penghormatan atas kultur kompetisi dengan nama fair play; kemempuan bekerja sama dan sikap saling percaya (Level of Trust, interpersonal Trust) dalam interaksi sosial; sikap hidup yang tolern dan moderat; kompetensi teknis yang dibutuhkan warga negara yang aktif seperti kemampuan menyeleksi informasi dan berpikir kritis; self determination dan kepercayaan kepada sistem hukum serta institusi kenegaraan.

\section{METODE PENELITIAN}

Penelitian ini dilakukan di kecamatan Rakit Kulim, Indragiri Hulu, Riau. Adapun yang menjadi informan dalam penelitian ini adalah pemangku adat Talang Mamak, pemerintah setempat, masyarakat suku Talang Mamak, dan para ahli budaya yang ada di Kecamatan Rakit Kulim. Penelitian ini menggunakan pendekatan kualitatif, dengan menggunakan metode etnografi. Penelitian etnografi fokus pada masyarakat, memilih informan yang diketahui memiliki pandangan yang luas dan mendalam terhadap aktivitas masyarakat yang diteliti. Tehnik pengumpulan data menggunakan observasi, wawancara, dokumentasi dan Triangulasi. Senada dengan pendapat pendapat Catherine Marshall, Gretchen B. Rossman (Sugiono, 2011: 225) menyatakan bahwa "the fundamental methods relied on by qualitative researchers for gathering information are, participation in the setting, direct observation, in-depth interviewing, document review". Maka dari itu, dalam penelitian ini menggunakan Tehnik pengumpulan data meliputi: Observasi, Wawancara, dokumentasi, dan Traingulasi. Analisis data mengacu pada langkah-langkah Miles dan Huberman (2007:16-19) menyatakan terdiri dari tiga alur kegiatan secara bersamaan meliputi: 
Reduksi Data, display data dan penarikan kesimpulan/verifikasi data. Metode penelitian ini untuk menjawab rumusan masalah yang terdapat dalam penelitian.

\section{PEMBAHASAN HASIL PENELITIAN Deskripsi Budaya suku Talang Mamak dalam bagian civic culture.}

Berdasarkan hasil penelitian bahwa Kebudayaan Suku Talang Mamak meliputi kelahiran, gawai gadang (upacara perkawinan), kematian, kumantan, dan mendanu. Dalam kebudayaan suku Talang Mamak yang membahas mengenai kelahiran meliputi, cuci lantai, upacara melahirkan dibantu oleh dukun, upacara timbang bayi, upacara beranggul dan khitanan. Dalam kebudayaan suku Talang Mamak yang mengenai gawai gadang dalam prosesinya meliputi bertandang, bertunangan, hataran, proses perkawinan, sabung ayam, dan penutup. Dalam proses kematian meliputi, menambak/naik tanah, cuci lantai, hari menuju, kemantan, tambat kubur, khitanan, melahirkan anak, timbang bayi, beranggul. Selajutnya mengenai kebudayaan Talang Mamak mengenai mendanau sebuah kebudayaan yang dilakukan secara bersamasama dalam pencarian ikan di danau. Sedangkan kumantan adalah sebuah kegiatan perdukunana untuk mengobati penyakit yang terdapat dalam masyarakat Talang Mamak. Dalam konsep kebudayaan menurut Sir Edward Burnett Taylor dalam Horton \& Chester, 1996:58; Harsojo, 1988:92; Soekanto; 2003:172; Sutarno. 2008:5: Sulaeman, 2012:35 dan Kusumohamidjojo, 2010:38 menyebut bahwa kebudayaan adalah kompleks keseluruhan dari pengetahuan, keyakinan, kesenian, moral, hukum, adat istiadat dan semua kemampuan dan kebiasaan yang lain yang diperoleh oleh seseorang sebagai anggota masyarakat. Sedangkan Menurut Geertz (1973:89): Kebudayaan adalah "pola dari pengertianpengertian atau makna yang terjalin secara menyeluruh dalam simbol-simbol yang ditransmisikan secara historis, suatu sistem mengenai konsepsi-konsepsi yang diwariskan dalam bentuk-bentuk simbolik yang dengan cara tersebut manusia berkomunikasi, melestarikan, dan mengembangkan pengetahuan dan sikap mereka terhadap kehidupan." Selanjutnya Menurut Wiranata, 2011:96-97 dari sekian banyak pemikiran para ahli tentang apakah sesungguhnya kebudayaan itu, secara umum inti pengerti kebudayaan :

1) Bahwa kebudayaan yang terdapat antara umat manusia itu sangat beraneka ragam,

2) Bahwa kebudayaan itu didapat dan diteruskan secara sosial melalui proses pembelajaran,

3) Bahwa kebudayaan itu terjabarkan dari komponen biologis, sosiologis, dan psikologis dari eksistensi manusia,

4) Bahwa kebudayaan itu berstruktur,

5) Bahwa kebudayaan itu memuat beberapa aspek,

6) Bahwa kebudayaan itu bersifat dinamis,

7) Bahwa nilai dalam kebudayaan itu bersifat relative

Berdasarkan teori diatas bahwa suku Talang Mamak memiliki sebuah kebudayaan yang mana dapat dilihat dari acara kelahiran, gawai gadang, kematian, kumantan dan mendanau. Selanjutnya Menurut Elfidayati, (2013) mengatakan tentang kebudayaan suku talang mamak yaitu:

"suku talang mamak berisikan upacaraupacara adat seperti gawai yaitu pesta pernikahan, kemantan yaitu pengobatan penyakit, tambat kubur yaitu acara seratus hari kematian dan memperbaiki kuburan untuk peningkatan status sosial, khitanan, upacara melahirkan dibantu oleh dukun, upacara timbang bayi, upacara beranggul yaitu upacara yang tujuannya untuk menghibur orang yang sedang mengalami kemalangan".

Sejalan dengan pendapat diatas menurut Ruben, (2010) tradisi-tradisi Suku Talang Mamak adalah sebagai berikut:

1) Kumantan: suatu acara berdukun untuk mengobati penyakit dan memberi makan pelindung kampung. Pada acara ini orang-orang yang akan diobati duduk di dekat dukun. Dukun menari-nari diikuti iringan musik dari alat musik tawak-tawak dan katubung. Sambil menari-nari dukun siap sedia 
untuk dimasuki roh leluhur. Acara berdukun dilakukan pada larut malam, biasanya sekitar jam 22.00.

2) Menambak/naik tanah: yakni suatu acara menimbun kuburan. Orang Talang Mamak bila meninggal akan dikuburkan, tetapi kuburan tidak langsung ditimbun penuh dengan tanah, melainkan hanya sedikit saja di bagian permukaan. Tanah itu ditahan dengan papan. Setelah 100 hari bila keluarga sepakat maka kuburan itu ditimbun dengan tanah dan diberi tanda. Itulah acara menambak.

3) Cuci lantai: yakni suatu acara adat yang berlaku untuk anak-anak yang baru lahir. Dalam acara ini si anak diberi nama dan akan mendapatkan orang tua asuh. Si anak juga akan dibawa ke sungai dan dimandikan di sana.

4) Gawai: yakni acara pernikahan. Pernikahan bisa terjadi bila pemuda dan pemudi sudah saling mencintai dan sepakat untuk berkeluarga. Si wanita akan mengikut ke rumah silakilaki dengan membawa pertanda dari laki-laki itu. Kemudian mereka akan naik ke rumah mangku, selanjutnya ke rumah batin. Akan tetapi perkawinan juga bisa terjadi bila pemuda dan pemudi kedapatan sedang berduaan pada malam hari. Yang seperti ini disebut dengan tergawal. Mereka akan langsung dinikahkan.

5) Mendanau: yakni suatu acara mencari ikan secara bersama ke suatu kolam.

6) Berjudi: berjudi juga merupakan acara adat dan dilaksanakan pada saat adanya pesta-pesta.

7) Menyabung ayam: menyabung ayam juga acara adat dan dilaksanakan pada pesta. Pada saat itu orang-orang akan saling bertaruh dengan uang.

8) Meratap: yakni suatu acara menangisi orang yang meninggal.

9) Merota: yakni acara masuk ke liang kubur oleh keluarga yang meninggal sebagai tanda bahwa dia tidak rela keluarganya meninggal, lebih baik dirinya yang meninggal. Ini tanda cinta kepada yang meninggal itu.

10) Hari Menuju: yakni acara bagi yang sudah meninggal 7 hari. Pada acara ini roh yang meninggal diantar ke tempatnya dengan tanda menebarkan daun-daun pisang di jalan sebagai jalan arwah yang meninggal.

Menurut Elfidayati, (2013) mengatakan tentang kebudayaan suku talang mamak yaitu:

"suku talang mamak berisikan upacaraupacara adat seperti gawai yaitu pesta pernikahan, kemantan yaitu pengobatan penyakit, tambat kubur yaitu acara seratus hari kematian dan memperbaiki kuburan untuk peningkatan status sosial, khitanan, upacara melahirkan dibantu oleh dukun, upacara timbang bayi, upacara beranggul yaitu upacara yang tujuannya untuk menghibur orang yang sedang mengalami kemalangan".

Dalam perkembangan kebudayaan yang ada masyarakat suku Talang Mamak masih mepertahankan kebudayaannya ditandai dengan masih adanya pergelaran-pergelaran kebudayaan dalam proses adat istiadat yang terdapat dalam masyarakat suku Talang Mamak.

Berdasarkan hasil penelitian Kebudayaan yang terdapat dalam masyarakat suku Talang Mamak merupakan bagian dari civic culture yang mana terdapat nilai civic culture yang ada dalam masyarakat suku Talang Mamak meliputi: Sikap Saling Percaya, Sikap Tanggung Jawab, Kemampuan Bekerja Sama, Religios, Tanggung Jawab, Solidaritas, Musyawarah, Kebersamaan, dan Gotong Royong.

Dalam konsep civic culture Menurut Winataputra (2012:57) Spesifik civic culture merupakan budaya yang menopang kewarganegaraan yang berisikan separangkat ideide yang dapat diwujudkan secara efektif dalam representasi kebudayaan untuk tujuan pembentukan identitas warganegara. Senada dengan pendapat diatas menurut Winataputra \& Budimansyah. (2012:233) Civic culture merupakan budaya yang menopang kewarganegaraan yang berisikan .... a set of ideas 
that can be embodied effectively in cultural representations for the purpose of shaping civic identities atau seperangkat ide-ide yang dapat diwujudkan secara efektif dalam representasi kebudayaan untuk tujuan pembentukan identitas warga negara. Selanjutnya Winataputra, (2006:62) unsur dari budaya kewarganegaran (civic culture) adalah civic virtue atau kebajikan atau ahlak kewarganegaraan yang mencakup keterlibatan aktif warganegara, hubungan kesejajaran/egaliter, saling percaya dan toleran, kehidupan yang kooperatif, solidaritas, dan semangat kemasyarakatan. Sednagkan Putnam, (1994) dalam Budimansyah \& Suryadi. (2008:186-187) Partisipasi ini dibangun atas hal-hal yang mendasar, yaitu

a) Egalitarianism atau hubungan timbal balik secara horizontal sesama warga.

b) Pluralisme, dimana perbedaan paham, kepercayaan, dan kepentingan sesame warga diterima sebagai kenyataan hidup yang harus dihargai, karena itu toleransi sosial politik memberi ciri krusial terhadap civic community.

c) Rasa saling percaya (trust) dan solideritas sesama warga.

Menurut Denny.J.A. (2006:52) Kini term civic culture ini digunakan sebagai label untuk merangkum berbagai nilai dan prilaku yang memperkukuh institus demokrasi. Elemen civic culture itu antara lain: penghormatan atas kultur kompetisi dengan nama fair play; kemempuan bekerja sama dan sikap saling percaya (Level of Trust, interpersonal Trust) dalam interaksi sosial; sikap hidup yang tolern dan moderat; kompetensi teknis yang dibutuhkan warga negara yang aktif seperti kemampuan menyeleksi informasi dan berpikir kritis; self determination dan kepercayaan kepada sistem hukum serta institusi kenegaraan.

Suku Talang Mamak memiliki sebuah kebudayaan yang mana kebudayaan tersebut meliputi kelahiran, gawai gadang (upacara perkawinan), kematian, kumantan, dan mendanu. Kebudayaan suku Talang Mamak merupakan bagian dari civic culture ini dibuktikan bahwa budaya suku Talang
Mamak terdapat sebuah nilai civic culture yang terdapat dalam masyarakat Talang mamak meliputi Sikap Saling Percaya, Sikap Tanggung Jawab, Kemampuan Bekerja Sama, Religios, Tanggung Jawab, Solidaritas, Musyawarah, Kebersamaan, dan Gotong Royong.

\section{Nilai Nilai-Nilai Kearifan lokal yang terkandung dalam budaya masyarakat suku Talang Mamak dalam bagian civic culture.}

Berdasarkan hasil penelitian bahwa suku Talang Mamak memiliki sebuah nilai kearifan lokal yang mana nilai kearifan lokal tersebut meliputi mengenai adat"lebih baik mati anak daripada mati adat", mengenai penggunaan lahan " pembakaran dalam pembersihan ladang", mengenai hukum waris" "Mati laki kerayat tinggal di bini, mati bini kerayat tinggal di laki; Harta di hutan dikuak diagi, harta di rumah tembilang ditempa, harta pembawa dibawa pulang", kedudukan anak laki-laki dan perempuan "Anak jantan disemendakan anak betina ditelikurkan". gawai gadang meliputi untuk laki-laki "utang lelaki kepada bini di carikan lauk, dicarikan asam garam, dibuatkan huma", sedangkan untuk perempuan "utang bini kepada laki ditanakan nasi, digulaikan ikan, disendokan dan disajikan makanan, tikar dibentangkan, kelambu digayutkan”. Kumantan yang digunakan meliputi "penggunaan tumbuhan". Dalam kehidupan sehari-hari adanya sebuah larangan "mengambek dak memintak, menyangkang dak betanya, menjaring dak bebungkal, dan bekata dak bebaris". Menurut Sartini, (2004:111 lokal wisdom (kearifan setempat) dapat dipahami sebagai gagasan-gagasan setempat (lokal) yang bersifat bijaksana, penuh kearifan, bernilai baik, yang tertanam dan diikuti oleh anggota masyarakatnya. Sedangkan Moendardjito dalam Ayat Rohaedi, (1986:40-41) bahwa unsur budaya daerah potensial sebagai lokal genius karena telah teruji kemampuannya untuk bertahan sampai sekarang. Ciri-cirinya :

a. Mampu bertahan terhadap budaya luar. 
b. Memiliki kemampuan mengakomodasi unsur-unsur budaya luar.

c. Mempunyai

kemampuan mengintegrasikan unsur budaya luar ke dalam budaya asli.

d. Mempunyai kemampuan mengendalikan.

e. Mampu memberi arah pada perkembangan budaya.

Menurut Alwasih, et al (2009:51) menyebut ciri-ciri kearifan lokal sebagai berikut : (1) berdasarkan pengalaman, (2) Teruji setelah digunakan berabad-abad, (3) dapat diadaptasi dengan kultur kini, (4) padu dalam praktek keseharian masyarakat dan lembaga, (5) lazim dilakukan oleh individu atau masyarakat secara keseluruhan, (6) bersifat dinamis dan terus berubah, dan (7) terkait dengan sistem kepercayaan.

Sejalan dengan pandangan tersebut, Wagiran (2012:330) merumuskan sebagai berikut :

Lokal wisdom is the knowledge that discovered or acquired by lokal people thourgh the accumulation of experiences in trials and integrated with the understanding of surrounding nature and culture. Lokal wisdom is dynamic by funcation of created lokal wisdom and connected to the global situation.

Secara umum karakteristik lokal memberikan pandangan tentang kearifan lokal telah digunakan secara turun menurun oleh para pelaku budayanya, kearifan lokal tidak akan pernah lepas dari ruang lingkup kebudayaanya, kepercayaan dan keterkaitan antara lingkungan alam dan sosial yang ada disekitarnya.

Gawai gadang meliputi untuk laki-laki "utang lelaki kepada bini di carikan lauk, dicarikan asam garam, dibuatkan huma", sedangkan untuk perempuan "utang bini kepada laki ditanakan nasi, digulaikan ikan, disendokan dan disajikan makanan, tikar dibentangkan, kelambu digayutkan”.

Ungkapan itu menurut Isjoni, (2005:7071) yaitu : "Utang laki-laki kepada bini, dicarikan lauk, dicarikan asam garam, dibuatkan buma, utang bini kepada laki digulaikan ikan, disendokan dan disajikan makanan, tikar dibentangkan, kelambu digayutkan".

Berdasarkan hasil penelitian dan teori diatas konsepsi mengenai kearifan lokal yang terdapat dalam suku Talang Mamak meliputi: "lebih baik mati anak daripada mati adat" "pembakaran dalam pembersihan ladang", "Mati laki kerayat tinggal di bini, mati bini kerayat tinggal di laki; Harta di hutan dikuak diagi, harta di rumah tembilang ditempa, harta pembawa dibawa pulang", Anak jantan disemendakan anak betina ditelikurkan", "utang lelaki kepada bini di carikan lauk, dicarikan asam garam, dibuatkan huma", "utang bini kepada laki ditanakan nasi, digulaikan ikan, disendokan dan disajikan makanan, tikar dibentangkan, kelambudigayutkan", "penggunaan tumbuhan", dan "mengambek dak memintak, menyangkang dak betanya, menjaring dak bebungkal, dan bekata dak bebaris.

Winataputra, (2006:62) unsur dari budaya kewarganegaran (civic culture) adalah civic virtue atau kebajikan atau ahlak kewarganegaraan yang mencakup keterlibatan aktif warganegara, hubungan kesejajaran/egaliter, saling percaya dan toleran, kehidupan yang kooperatif, solidaritas, dan semangat kemasyarakatan. Senada dengan pendapat diatas Menurut Denny.J.A. (2006:52) Kini term civic culture ini digunakan sebagai label untuk merangkum berbagai nilai dan prilaku yang memperkukuh institus demokrasi. Elemen civic culture itu antara lain: penghormatan atas kultur kompetisi dengan nama fair play; kemempuan bekerja sama dan sikap saling percaya (Level of Trust, interpersonal Trust) dalam interaksi sosial; sikap hidup yang tolern dan moderat; kompetensi teknis yang dibutuhkan warga negara yang aktif seperti kemampuan menyeleksi informasi dan berpikir kritis; self determination dan kepercayaan kepada sistem hukum serta institusi kenegaraan.

Berdasarkan dari konsepsi teori diatas mengenai civic culture, maka kearifan lokal yang terdapat dalam Suku Talang Mamak merupakan bagian dari civic culture ini 
ditandai dengan adanya nilai-nilai yang terkandung dalam kearifan lokal yang bisa dijadikan sebuah jati diri, identitas, dan nilainilai kebajikan. Dalam konteks ini, nilai-nilai kearifan lokal yang bisa dijadikan jati diri dan identitas bangsa yaitu, cinta tanah air, nilai kesetaraan, kepedulian, Tanggung Jawab, nilai kemandirian dan kebaikan.

Suku Talang Mamak memiliki sebuah kearifan lokal yang mana kearifan lokal yang telah ditemukan dalam penelitian bahwa suku Talang Mamak merupakan bagian dari civic culture ini dibuktikan bahwa kearifan lokal suku Talang Mamak terdapat sebuah nilai civic culture yang terdapat dalam masyarakat Talang mamak meliputi: cinta tanah air, nilai kesetaraan, kepedulian, Tanggung Jawab, nilai kemandirian dan kebaikan.

\section{Pelestarian Pelestarian Kebudayaan dan Nilai-nilai Kearifan Lokal yang terkandung dalam budaya masyarakat suku Talang Mamak.}

Pelestarian merupakan sebuah upaya dalam mempertahankan sebuah kebudayaan yang terdapat dalam masyarakat setempat. Berdasarkan hasil penelitian bahwa pelestarian kebudayaan dan nilai-nilai kearifan lokal yang terkandung dalam budaya masyarakat suku Talang Mamak dengan cara melakukan upacara-upacara adat, memberikan pengetahuan dan menjelaskan maknamakna yang terdapat pada setiap pelaksanaan upacara, melibatkan pemuda-pemudi dan para generasi muda untuk ikut melaksanakan upacara adat, cara mengikuti pertandingan kebudayaan yang dilombakan oleh pemerintah daerah maupun international, dan malaksanakan sebuah festival di tingkat kabupaten berupa lomba festival. Senada dengan pendapat William Lim dan Tan Hock Beng, 1998 dalam Hamka, (2013:9). Strategi tersebut menghasilkan 4 konsep arsitektur kotemporer vernacular, yakni:

1) Reinvigorating tradition" - "evoking the vernacular" by way of "a genuine reinvigoration of traditional craft wisdom"

2) Reinventing tradition" - "the search for new paradigms"
3) Extending tradition" - "using the vernacular in a modified manner"

4) Reinterpreting tradition" - "the use of contemporary idioms" to transform traditional formaldevices in "refreshing ways"

Maka dari itu, pelestarian yang dilakukan oleh masyarakat suku Talang Mamak yang masyarakat suku Talang Mamak memberikan pengetahuan mengenai kebudayaan kepada generasi muda, mengikuti perlombaan mengenai kebudayaan dan festival. Kesemua ini dilakukan agar masyarakat suku Talang Mamak dapat melestarikan kebudayaan yang telah diwariskan oleh nenek moyang suku Talang Mamak.

\section{Kendala dan Upaya dalam pelestarian kebudayaan dan nilai-nilai kearifan lokal yang terkandung dalam budaya masyarakat suku Talang Mamak.}

Berdasarkan hasil penelitian yang telah dilakukan dalam pelestarian kebudayaan suku Talang Mamak terdapat beberapa yang menjadi kendala dan upaya dapat dilihat sebagai berikut:

Dalam faktor ekonomi dalam pelaksanaan gawai gadang ada acara yang dilaksanakan selama 6-7 hari pelaksanaan ini dilaksanakan membutuhkan biaya 100 JT dalam pelaksanaan. Tetapi kami suku Talang Mamak kebanyakan hanya melaksanakan 3-4 hari sebab faktor ekonomi. Upaya yang kami lakukan untuk pelaksanaan ini kami bersamasama mengumpulkan uang untuk melaksanakan acara ini.

Dalam faktor rendahnya pendidikan, dalam pengenalan budaya kami disebabkan masyarakat kami tidak memiliki pengetahuan yang luas untuk menggali kebudayaan Upaya yang dilakukan hanya memberikan pandangan kepada masyarakat kami untuk melanjutkan pendidikan yang lebih baik lagi walaupun kita harus sekolah jauh tetapi kita kembali membangun daerah kita. Keseluruhan ini hanya sebuah motivasi yang diberikan kepada anak-anak kami agar mereka melanjutkan pendidikan kejenjang yang lebih tinggi. 
Dalam faktor kepercayaan diri, sebagian pemuda saja yang memiliki kepercayaan diri yang rendah. Kami menjelaskan kepada para pemuda-pemudi agar kita melestarikan kebudayaan kita agar kebudayaan kita bisa bertahan hingga bumi ini juga hancur.

Dalam faktor transportasi, jalur transportasi untuk menuju kedaerah-daerah Talang mamak sangat sulit, kadang membutuhkan waktu yang cukup lama, jadi para panitia bekerja ekstra dalam mengundang suku Talang Mamak yang ada di dalam hutan. Dengan acara festival batang gansal ini kami bisa melestarikan kebudayaan suku Talang Mamak dan Melayu agar bisa bertahan dalam terjangan kebudayaan dari luar yang bersifat negatif. Upaya dilakukan yaitu memohon kepada pemeritnah kabupaten indragiri hulu maupun provinsi riau agar memberikan pembagunan jalan yang layak untuk menuju kepemukiman suku Talang Mamak.

\section{PENUTUP}

1) Suku Talang Mamak memiliki sebuah kebudayaan yang mana kebudayaan tersebut meliputi kelahiran, gawai gadang (upacara perkawinan), kematian, kumantan, dan mendanu. Kebudayaan suku Talang Mamak merupakan bagian dari civic culture ini dibuktikan bahwa budaya suku Talang Mamak terdapat sebuah nilai civic culture yang terdapat dalam masyarakat Talang mamak meliputi Sikap Saling Percaya, Sikap Tanggung Jawab, Kemampuan Bekerja Sama, Religios, Tanggung Jawab, Solidaritas, Musyawarah, Kebersamaan, dan Gotong Royong.

2) Kearifan lokal yang terdapat dalam suku Talang Mamak meliputi: "lebih baik mati anak daripada mati adat", " pembakaran dalam pembersihan ladang", "Mati laki kerayat tinggal di bini, mati bini kerayat tinggal di laki; Harta di hutan dikuak diagi, harta di rumah tembilang ditempa, harta pembawa dibawa pulang", Anak jantan disemendakan anak betina ditelikurkan”, "utang lelaki kepada bini di carikan lauk, dicarikan asam garam, dibuatkan huma”, "utang bini kepada laki ditanakan nasi, digulaikan ikan, disendokan dan disajikan makanan, tikar dibentangkan, kelambu digayutkan", "penggunaan tumbuhan", dan "mengambek dak memintak, menyangkang dak betanya, menjaring dak bebungkal, dan bekata dak bebaris. Kearifan lokal yang telah ditemukan dalam penelitian bahwa suku Talang Mamak merupakan bagian dari civic culture ini dibuktikan bahwa kearifan lokal suku Talang Mamak terdapat sebuah nilai civic culture yang terdapat dalam masyarakat Talang mamak meliputi: cinta tanah air, nilai kesetaraan, kepedulian, Tanggung Jawab, nilai kemandirian dan kebaikan.

3) Pelestarian yang dilakukan oleh masyarakat suku Talang Mamak yang masyarakat suku Talang Mamak memberikan pengetahuan mengenai kebudayaan kepada generasi muda, mengikuti perlombaan mengenai kebudayaan dan festival.

4) Kendala yang terdapat dalam masyarakat suku Talang Mamak meliputi beberapa faktor meliputi: faktor ekonomi, faktor pendidikan, faktor kepercayaan diri, dan faktor transportasi. Upaya faktor ekonomi: melakukan iuran bersama, Faktor Pendidikan: Memotivasi kepada anak agar mengutamakan pendidikan, Faktor Kepercayaan diri: memberikan motivasi bahwa suku Talang Mamak merupakan bagian dari kebudayaan kita yang harus dipertahankan, dan Faktor tansportasi: meminta bantuan kepada pemerintah kabupaten kota maupun provinsi agar adanya pembagunan jalan kepemukiman suku Talang Mamak.

\section{DAFTAR PUSTAKA}

Alwasih, C., Suryadi,K., Karyono,T. (2009). Etnopedagogi: Landasan Praktek Pendidikan dan Pendidikan Guru. Bandung; Kiblat Universitas Pendidikan Indonesia 
Ayatrohaedi. (1986). Keperibadian Budaya Bangsa (Local Genius). Jakarta: Pustaka Jaya

Budimansyah, D. \& Suryadi, K. (2008). PKn dan Masyarakat Multikultural. Bandung: Program Studi Pendidikan Kewarganegaraan Sekolah Pascasarjana, Universitas Pendidikan Indonesia.

Denny.J.A. (2006). Catatan Politik.

LKIS:Yogyakarta.

Geertz, Clifford.(1973). The Interpretation of Cultures: Selected Essays.New York: Basic Books

Harsojo. (1988). Pengantar Antropologi. Bandung: Binacipta.

Horton, Paul B dan Chester L. Hunt. (1996). Sosiologi. Jakarta: Penerbit Erlangga.

Isjoni, (2005). Orang Talang Mamak:Prespektif Antropologi

Ekonomi. UnriPress. Pekanbaru.

Kusumohamidjojo, B.(2010). Filsafat Kebudayaan:Proses Realisasi Manusia. Yogyakarta: Jalasutra

Miles dan Huberman.(2007). Analisis Data Kualitatif Buku Sumber Tentang Metode-motode baru. Jakarta : Universitas Indoneisa Press.

Rosidi. A. (2011). Kearifan Lokal : Dalam Prespektif Budaya Sunda. Bandung : PT Kiblat Buku Utama

Soekanto, Soerjono.(2003). Sosiologi Sutau Pengantar. Jakarta: PT. Raja Grafindo Persada.

Sugiono. (2011). Metode Penelitian Pendidikan (Pendekatan Kuantitatif, Kualitatif dan $R \quad \& \quad D)$. Bandung: Alfabeta.

Sulaeman, M.M. (2012). Ilmu Budaya Dasar. Bandung: PT. Refika Aditama.
Sutarno. (2008) Bahan ajar catak pendidikan Multicultural. Jakarta: Dirjen Dikti Depdiknas.

Winataputra, U.S. (2012). Pendidikan Kewarganegaraan Dalam Perspektif Pendidikan Untuk Mencerdaskan Kehidupan Bangsa (Gagasan, Instrumentasi, dan Praksis). Bandung: Widya Aksara Press.

Winataputra,U.S. (2006). Pendidikan Kewarganegaraan dalam prespektif Pendidikan untuk mencerdaskan kehidupan bangsa,(Gagasan, Instrumentasi, dan Praksisi). Bandung : Widya Aksara Press.

Wiranata, I Gede A.B.(2011). Antropologi Budaya. Bandung; PT Citra Aditya Bakti.

Wagiran. (2012). Pengembangan Karakter Berbasis kearifan lokal Hamemayu Hayuning Bawana, Dalam Jurnal Pendidikan Karakter. Tahun II (2) , 329-339

\section{Internet}

Elfidayati.(2013). Adat Istiadat Suku Talang Mamak \{Online\} Tersedia di http://agama-islamjawa.blogspot.com/2013/09/adatistiadat-suku-talang-mamak.html $\quad\{20$ Oktober 2013\}

FB Anggoro. (2010). Talang Mamak dan Masyarakat Adat yang Merana \{Online\}.Tersedia:http://sains.kompas. com/read/2010/04/03/23204793/Talang .Mamak.dan.Masyarakat.Adat.yang.Me rana. $\{20$ Oktober 2013$\}$

Ruben, (2009). Selayang Pandang Talang Mamak \{Online\} Tersedia: http://talangmamak.blogspot.com/2009 /10/selayang-pandang-talangmamak.html. $\quad\{20$ Oktober 2013\} 